\title{
Injected Treatments for Management of Madrone Canker
}

\author{
Marianne Elliott and Robert L. Edmonds
}

\begin{abstract}
Pacific madrone (Arbutus menziesii) has been experiencing a decline in the Puget Sound area, primarily as a result of a canker disease caused by the fungus Fusicoccum arbuti. Cultural methods such as prevention of stress and wounding are recommended to control canker diseases on trees. In addition to these, injected treatments can be used to protect valuable Pacific madrone trees in urban areas. An experiment testing injectable chemical fungicides and plant activators was performed on Pacific madrone trees inoculated with $F$. arbuti. There was little correlation between fungicidal activity in culture and canker reduction in the field tests. Two treatments that were effective in minimizing canker growth in inoculated madrones were Arbotect ${ }^{\circledR}$ (Syngenta Crop Protection Inc., Greensboro, NC, U.S.; a triazole fungicide) and BioSerum ${ }^{\mathrm{TM}}$ (phosphorous acid). Cankers on wound inoculations were $50 \%$ smaller than the control group and no infections occurred on surface-inoculated treatments. Increased callusing was observed on cankers on trees with these treatments and the mode of action for these chemicals is probably stimulation of plant defenses rather than fungicidal action. Phosphorous acid is recommended in addition to cultural methods that improve tree vigor for high-value madrone trees in urban landscapes; however, heavily infected trees that have lost most of their crown will probably not benefit.

Key Words. Arbotect ${ }^{\circledR}$; Botryosphaeria; canker; Fusicoccum; injectible fungicide; Pacific madrone (Arbutus menziesii); phosphorous acid; plant activator.
\end{abstract}

Pacific madrone (Arbutus menziesii) is a broadleaf evergreen tree whose native range extends from southern California, U.S. to coastal British Columbia, Canada and is an important landscape tree in Seattle, Washington, U.S. city parks, streets, and homes. Pacific madrones are a drought-tolerant, lowmaintenance alternative to some other popular species such as oak or maple.

There is much interest in a method that will reduce the impact of diseases, like madrone canker, on some of the larger, more valuable trees.

Pacific madrones have been experiencing a decline during the past 30 years (Davison 1972; Hunt et al. 1992). The decline first became obvious after a period of drought in the late 1960s in urban areas of Seattle, Washington, where there was an aging population of madrone trees. A canker disease caused by the fungus Fusicoccum arbuti (formerly known as Hendersonula toruloidea or Nattrassia mangiferae) is primarily responsible for the decline (Elliott et al. 2002; Farr et al. 2005). This fungus has a sexual stage in the genus Botryosphaeria, a group of latent, endophytic fungi in twigs and branches, and become pathogenic when the tree is under stress (Crist and Schoenweiss 1975; Ma et al. 2001a). Because Botryosphaeria can exist in a latent or asymptomatic form in healthy tissue until reduction of host defenses permits symptom expression, it is not always possible to detect and/or eradicate the fungus from trees.

Foliar applications of systemic fungicides have been effective against Botryosphaeria infections on orchard crops (Lonsdale and Kotze 1993; Li et al. 1995; Brown-Rytlewski and McManus 2000; Ma et al. 2001b, 2001c). Symptoms were reduced in apple trees sprayed with kresoxim-methyl, benomyl, or trifloxystrobin, but the fungus was still present in xylem tissue, suggesting that it was not eradicated and would produce symptoms at a later time when the host was susceptible (Brown-Rytlewski and McManus 2000).

Plant activators are chemicals that are not necessarily toxic to fungi or host plants, but stimulate defense responses in plants.
This response is termed systemic acquired resistance (SAR) and has been well studied in crop plants but not as extensively in trees until recently. There are several mechanisms that operate in the host during a SAR response, including induction of enzymes such as chitinase, peroxidase, and lipase. Chemicals, including jasmonic acid and salicylic acid, are produced and act as messengers that turn on other genes resulting in the defense response (Percival 2001). Phosphorous acid has been used with some success as a plant activator in providing systemic protection against Phytophthora diseases of trees (Fenn and Coffey 1983; Afek and Sztejnberg 1989; Anderson et al. 1989). Plants treated with Fosetyl-Al, an organophosphate chemical, have increased levels of phytoalexins (Percival 2001). Triazole fungicides also have been shown to behave as plant activators (Lonsdale and Kotze 1993).

Plant activators and systemic fungicides are applied to trees by foliar spraying, soil drenches, and injection directly into the xylem. Spraying and soil drenches are not options in urban or forested environments when there is concern about the effects of the chemical on nontarget areas and beneficial organisms such as mycorrhizal fungi, epiphytic fungi such as Trichoderma spp., and yeasts, and so these methods are mostly used in orchards. Injection of chemicals into the xylem allows the chemical to be delivered directly to affected tissues in the case of vascular wilts and cankers. Injected treatments have been used to manage Dutch elm disease (DED) (Lanier 1988; Haugen and Stennes 1999) and Cytospora canker of Prunus (Helton and French 1962; Helton and Harvey 1963). Injecting chemicals into the root flare and using a shallow, small-diameter hole into the most recent sapwood have been shown to provide the most uniform distribution of the chemical and best wound closure after injection (Stipes 1988). Dosages are based on calculations involving tree diameter and are calibrated to be slightly less than the concentration that would be phytotoxic. The chemicals can be delivered using two injection methods: microinjection, in which a small volume of concentrated chemical is injected into the xylem un- 
Table 1. In vitro testing of fungicides and plant activators. ${ }^{2}$

\begin{tabular}{llll}
\hline Fungicide & Active ingredient & Mode of action & Percent inhibition \\
\hline Tebuject $^{\mathrm{y}}$ & Tebuconazole & Triazole fungicide, DMI & 100 \\
Fungisol $^{\mathrm{y}}$ & Debacarb, carbendazim & Benzimidizole fungicide, NA & 100 \\
Cleary $3336^{\text {Arbotect }}{ }^{\text {बy }}$ & Carbendazim & Benzimidizole fungicide, NA & 100 \\
Alamo $^{\mathrm{y}}$ & Thiabendizole & Benzimidizole fungicide, NA & 100 \\
Phyton $^{\mathrm{y}}$ & Propiconazole & Triazole derivative fungicide, DMI & 100 \\
Cambistat $^{\mathrm{y}}$ & Copper & Inorganic fungicide, EI & 100 \\
Rovral $_{\text {Bayleton }}$ & Paclobutrazole & Fungicide and plant activator, DMI \\
NuCop & Iprodione & Dicarboximide fungicide, NA & 100 \\
Cinnamite & Triadimefon & Triazole fungicide, DMI & $75-100$ \\
Kaligreen & Copper & Inorganic fungicide, EI & $75-100$ \\
Subdue Maxx & Cinnamaldehyde & Broad spectrum insecticide/miticide/fungicide \\
Aliette & Potassium bicarbonate & Inorganic fungicide & $75-100$ \\
M-pede & Mefanoxam & Acylalanine fungicide, NA & $75-100$ \\
Actigard & Fosetyl-Al (organic phosphate) & Plant activator, EI & $<50$ \\
Compass & Potassium salts of fatty acids & Inorganic fungicide & $<50$ \\
BioSerum & Acibenzolar-s-methyl & Strobilurin & Plant activator \\
Control & Phosphorous acid & Fungicide, ET & $<50$ \\
\hline
\end{tabular}

${ }^{\mathrm{z}}$ Results were based on fungal growth after 7 days at $25^{\circ} \mathrm{C}\left(77^{\circ} \mathrm{F}\right)$. Percent radial growth inhibition was calculated as the difference from control growth.

${ }^{\mathrm{y}}$ Chemicals used in the field tests.

$\mathrm{DMI}=$ sterol demethylation inhibitor; $\mathrm{NA}=$ nucleic acid and protein synthesis inhibitor; $\mathrm{ET}=$ electron transport disruptor; EI $=$ nonspecific enzyme inhibitor; $\mathrm{N} / \mathrm{A}=$ not applicable.

der pressure, and infusion, in which a large volume of dilute solution is fed into the tree through gravity and taken up in the transpiration stream. Treatments should be performed on a day when the tree is actively transpiring and after a period of heavy rainfall for best results (Stipes 1988). These methods do not eradicate the pathogenic fungus, but reduce symptom expression and inoculum density so that the tree can be healthy enough to defend itself. Injected fungicide or plant activator treatments in combination with cultural methods to improve tree vigor have the most likelihood of success. Injection treatments on DED are advised when there is no more than $5 \%$ to $10 \%$ of the crown affected by disease. In general, injection treatments are not recommended for trees with severe disease symptoms (Lanier 1988). Trees of reduced vigor are less likely to recover from injuries sustained during injection. There are no reports of injected treatments being used to manage Botryosphaeria diseases on trees.

The best treatments for madrone canker are ones that will improve overall tree vigor and include cultural methods such as sanitation, prevention of wounding, and improving soil water retention. Additional protection can be used in the form of chemical treatments, especially on high-value trees. Systemic fungicides and plant activators will give additional disease resistance, but are costly and can be damaging in some situations.

The objective of this study was to evaluate the ability of several injected chemicals to reduce damage to Pacific madrone caused by the canker pathogen $F$. arbuti.

\section{METHODS}

\section{In Vitro Testing of Fungicides}

Eighteen fungicides and plant activators were tested for efficacy against $F$. arbuti in culture (see Table 1 for list; mode of action is indicated). Two hundred parts per million active ingredient of each chemical was added to $2 \%$ malt extract agar. Controls were plates with $2 \%$ malt extract agar and no added chemical. Nine isolates of $F$. arbuti collected from the range of Pacific madrone, from southern California to Washington State, were tested using three replicates of each fungal isolate. Plates were inoculated from plugs taken from active cultures and incubated at $25^{\circ} \mathrm{C}$ $\left(77^{\circ} \mathrm{F}\right.$; the optimal temperature for $F$. arbuti radial growth) and fungal radial growth was measured at intervals of 7 days for 1 month and expressed as millimeters per day.

\section{Field Tests of Systemic Treatments}

The field tests took place on Lopez Island, Washington. Forests in this region are drier than those on the mainland as a result of the influence of the Olympic Mountains and Vancouver Island situated southwest and west northwest of the San Juan Islands. These land masses create a "rain shadow" effect that produces less rainfall in the islands than the rest of northern Puget Sound. At the nearest weather station at Olga on Orcas Island, the average high temperature in July is $21^{\circ} \mathrm{C}\left(69.8^{\circ} \mathrm{F}\right)$, and the average low in January is $2^{\circ} \mathrm{C}\left(35.6^{\circ} \mathrm{F}\right)$ (WRCC 2006). Winter temperatures are usually mild, except when cold, arctic air funnels down the Fraser River Valley from Canada and drastically lowers temperatures. Winds may also have a drying effect, pulling moisture from vegetation and surface water, and creating drought stress during low rainfall periods.

One hundred twenty-eight Pacific madrone trees were selected for field tests of the chemical treatments. These trees were located in a forested area with Douglas fir (Pseudotsuga menziesii) canopy dominants. The madrones formed a layer under the Douglas fir and many showed signs of competition for space and light. Most of the trees were intermediate or suppressed crown classes and growing at the edge or interior of the stand. The stand was considered to be intermediate in moisture conditions between dry and moist woodland. Soils are deeper on this site (San Juan County Health and Community Services 2000) than in other areas of the San Juan Islands and have a thick duff layer. Typical shrubs were salal (Gaultheria shallon), Oregon grape 
Table 2. Characteristics of Pacific madrone trees used in the fungicide injection study $(n=128)$.

\begin{tabular}{lll}
\hline & Mean & Range \\
\hline Diameter $(\mathrm{cm})$ & $14.4(5.8$ in) & $70-2.5(28-1 \mathrm{in})$ \\
Percent dieback & 40.2 & $99.0-9.0$ \\
Percent crown (including dead branches) & 66.1 & $100-30$ \\
Percent live foliage & 40.5 & $90.3-0.5$ \\
\hline
\end{tabular}

(Mahonia nervosa), ocean spray (Holodiscus discolor), and little wild rose (Rosa gymnocarpa).

Many of the trees in the stand were infected with $F$. arbuti in varying degrees of severity. Lopez Island is in an area severely affected by Pacific madrone decline (USFS 2003) and cankers on some trees were at least 15 years old as estimated by the number of callus layers. These trees on Lopez Island were good candidates for treatment because Fusicoccum is more aggressive on stressed trees and any treatment that was successful on them could have a good possibility of being effective on urban trees taking into account environmental factors that may influence disease development.

Each tree was evaluated and data were collected on diameter at breast height (dbh) and percent dieback, crown, and live foliage (Table 2) and randomly placed into one of eight treatment groups with 16 trees per group. The chemical treatments selected for the field tests were Alamo, Arbotect ${ }^{\circledR}$, BioSerum ${ }^{\mathrm{TM}}$, Cambistat, Fungisol, Phyton, Tebuject, and a water control (see list in Table 1). These chemicals were selected based on their behavior in vitro and also to represent different chemical modes of action. All chemicals except BioSerum ${ }^{\mathrm{TM}}$ caused $100 \%$ inhibition of mycelial growth in vitro, but BioSerum ${ }^{\mathrm{TM}}$ was selected for use in field tests because of its plant activator properties. Injection treatments were applied in Summer 2002 according to the label instructions for elm or oak.

The test madrones were inoculated in September 2002 with a single isolate of $F$. arbuti taken from a Pacific madrone tree in Port Townsend, Washington. This isolate was chosen because it was close to the field site in geographic origin. Three wounds were made on branches of each tree and a small amount of fungal inoculum (approximately $3 \mathrm{~mm}^{3}\left[0.12 \mathrm{in}^{3}\right]$ ) from a culture growing on malt extract agar was inserted into each wound, which was then covered with tape to retain moisture. In addition, three areas were treated by placing fungal inoculum on the bark surface without wounding.
Canker size was measured in centimeters squared in the summer of 2003 using the formula for area of an ellipse (Equation 1):

$$
\begin{aligned}
\text { Area }= & \Pi * \mathrm{a} * \mathrm{~b}, \text { where } \mathrm{a} \text { and } \mathrm{b} \text { are the major and minor } \\
& \text { axes of the ellipse. }
\end{aligned}
$$

Foliar samples were taken from three trees in each treatment group and analyzed for total phenolic content to estimate the tree's defense response. Total phenols were measured using a modified Prussian blue method (Graham 1992).

\section{Statistical Analysis}

Differences between treatment groups in both in vitro and field tests were determined using one-way analysis of variance in SPSS version 10.0. Levene's homogeneity of variance test was performed and Dunnett's T3 test for homogeneous subsets was used on groups with unequal variance (StatSoft 2004). For data that did not fit the normal distribution, the Kruskal-Wallis test was used instead of one-way analysis of variance.

\section{RESULTS}

\section{In Vitro Testing of Fungicides}

In general, the triazole and benzimidazole fungicides were the most inhibitory to radial growth of all isolates. The results of the in vitro tests are given in Table 1.

As expected, the plant activators showed little activity in culture because their effect is to create a defense response in the plant host. Inorganic fungicides based on copper and potassium salts performed less well than the organic fungicides. There were statistically significant differences among isolates in some of the fungicidal treatments (Table 3). Complete growth inhibition of all isolates was seen in the Tebuject, Alamo, Fungisol, Cleary 3,336 , and Phyton treatments. These chemicals were used in the field tests (except for Cleary 3,336). No inhibition of any isolate occurred in BioSerum $^{\mathrm{TM}}$, Aliette, and M-pede treatments, and fungal growth was stimulated in some cases.

\section{Field Tests of Systemic Treatments}

All of the wound-inoculated trees developed cankers. Cankers on all of the injected treatments were smaller than the controls (Table 4), but the phosphorous acid (BioSerum ${ }^{\mathrm{TM}}$ ) treatment was the most effective compared with the untreated control group and canker area was reduced by more than $50 \%$ in $2003(P=$ $0.01)$ and almost $70 \%$ in $2004(P=0.003)$. Only 3\% of all surface inoculations developed cankers. The treatment groups in

Table 3. Percent inhibition of mycelia growth of nine isolates of Fusicoccum arbuti from Washington and California in culture with 200 ppm fungicide. ${ }^{2}$

\begin{tabular}{lllllll}
\hline Isolate & Actigard & Bayleton & Compass & Kaligreen & Nucop & Subdue Maxx \\
\hline 1. King Co., WA & $44.8 \mathrm{ab}$ & $82 \mathrm{c}$ & $50.2 \mathrm{ab}$ & $-5.1 \mathrm{ab}$ & $78.4 \mathrm{ab}$ & $3.8 \mathrm{ab}$ \\
2. King Co., WA & $51.1 \mathrm{ab}$ & $\mathrm{nt}$ & $45.7 \mathrm{ab}$ & $22.6 \mathrm{c}$ & $80.0 \mathrm{ab}$ & $2.2 \mathrm{ab}$ \\
3. King Co., WA & $54.8 \mathrm{~b}$ & $100 \mathrm{~d}$ & $64.8 \mathrm{~b}$ & $15.4 \mathrm{abc}$ & $86.9 \mathrm{~b}$ & $15.1 \mathrm{~b}$ \\
4. Vashon, WA & $27.8 \mathrm{a}$ & $78.5 \mathrm{bc}$ & $47.5 \mathrm{ab}$ & $18.9 \mathrm{bc}$ & $75.8 \mathrm{ab}$ & $8.0 \mathrm{ab}$ \\
5. Vashon, WA & $45.9 \mathrm{ab}$ & $77.9 \mathrm{~b}$ & $40.2 \mathrm{a}$ & $15.5 \mathrm{abc}$ & $75.6 \mathrm{ab}$ & $0.7 \mathrm{ab}$ \\
6. Trinity Co., CA & $42.6 \mathrm{ab}$ & $100 \mathrm{~d}$ & $50.9 \mathrm{ab}$ & $-1.4 \mathrm{ab}$ & $76.7 \mathrm{ab}$ & $4.3 \mathrm{ab}$ \\
7. Nevada Co., CA & $50.1 \mathrm{ab}$ & $71.7 \mathrm{a}$ & $56.3 \mathrm{a}$ & $22.9 \mathrm{c}$ & $71.4 \mathrm{a}$ & $7.2 \mathrm{ab}$ \\
8. Santa Cruz Co., CA & $43.5 \mathrm{ab}$ & $79.3 \mathrm{bc}$ & $50.5 \mathrm{ab}$ & $-5.1 \mathrm{a}$ & $74.4 \mathrm{ab}$ & $0.47 \mathrm{ab}$ \\
9. Santa Cruz Co., CA & $39.4 \mathrm{ab}$ & $77.6 \mathrm{~b}$ & $31.4 \mathrm{a}$ & $20.8 \mathrm{bc}$ & $69.7 \mathrm{a}$ & $-6.1 \mathrm{a}$ \\
\hline
\end{tabular}

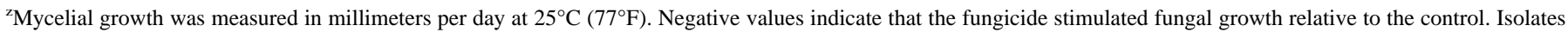
with the same letter in each fungicide column are not different in percent inhibition $(P=0.05$, Dunnett's T3 test).

nt $=$ not tested. 
Table 4. Effect of injected treatments of fungicides and plant activators on Pacific madrone canker growth. ${ }^{2}$

\begin{tabular}{lll}
\hline Treatment & 2003 & 2004 \\
\hline Control & $124.85(19.35) \mathrm{b}$ & $192.42(29.83) \mathrm{c}$ \\
Alamo & $88.43(13.71) \mathrm{ab}$ & $113.97(17.67) \mathrm{abc}$ \\
Arbotect $^{\circledR}$ & $83.13(12.89) \mathrm{ab}$ & $93.61(14.51) \mathrm{ab}$ \\
BioSerum $^{\mathrm{TM}}$ & $48.81(7.57) \mathrm{a}$ & $62.72(9.72) \mathrm{a}$ \\
Cambistat $_{\text {Fungisol }}$ & $102.83(15.94) \mathrm{b}$ & $165.69(25.68) \mathrm{bc}$ \\
Phyton & $92.54(14.34) \mathrm{ab}$ & $177.77(27.55) \mathrm{bc}$ \\
Tebuject & $100.03(15.50) \mathrm{b}$ & $117.21(18.17) \mathrm{abc}$ \\
\hline
\end{tabular}

${ }^{z}$ Mean area of inoculated canker in centimeters squared (inches squared) is given for each treatment during a 2-year period measured in 2003 and 2004. Treatments with the same letter in year column are not significantly different at $P=0.05$ (Dunnett's T3 test).

which surface inoculations developed into cankers were Alamo (7\%), Fungisol (13\%), Phyton (21\%), and control (17\%).

Although the differences were not significant, concentrations of phenolic defense chemicals were higher in trees treated with phosphorous acid, whereas the chemical itself was ineffective as a fungicide when tested in culture. The fungicide treatment groups were not significantly different when further samples were collected on the same age foliage in 2004 (1 year after treatment). Levels of foliar phenolics were highest in the Arbotect $^{\circledR}$ and BioSerum ${ }^{\mathrm{TM}}$ treatments, but these decreased after 1 year (Table 5). Values for other treatments increased after 1 year in the same foliage. In new foliage 1 year after treatment, the difference between groups was significant $(P=0.011$, KruskalWallis test) with the control and Cambistat treatments having the lowest amount of foliar phenolics and Phyton the highest.

No relationship was found between tree dbh and canker area for individual treatments for both years. A similar result was obtained for the relationship between total foliage and canker area, except in the Arbotect ${ }^{\circledR}$ treatment, in which trees with more foliage had smaller cankers $\left(\mathrm{r}^{2}=0.55, P=0.04\right.$ for $2003, \mathrm{r}^{2}=$ $0.64, P=0.02$ for 2004). There was more of a difference in canker size between treatments 1 year after treatment, and treatment effects seemed more important than the initial health of the tree.

\section{DISCUSSION}

\section{In Vitro Testing of Fungicides}

Because chemical fungicides have not been used with $F$. arbuti, the concentration of $200 \mathrm{ppm}$ active ingredient was chosen based

Table 5. Concentrations of total phenolic chemicals (milligrams per gram dry weight) in madrone foliage for each injected fungicide treatment. ${ }^{z}$

\begin{tabular}{llll}
\hline Treatment & 2003 & 2004, old foliage & 2004, new foliage \\
\hline Control & 50.4 & 58.9 & 36.9 \\
Alamo & 34.4 & 61.7 & 51.3 \\
Arbotect $^{\circledR}$ & 58.4 & 41.1 & 54.8 \\
BioSerum $^{\mathrm{TM}}$ & 59.4 & 54.3 & 43.8 \\
Cambistat $^{\text {Fungisol }}$ & 52.9 & 40.3 & 39.2 \\
Phyton & 51.6 & 52.1 & 51.3 \\
Tebuject & 58.3 & 58.6 & 61.4 \\
\hline
\end{tabular}

${ }^{\mathrm{z}}$ Samples were taken 9 (2003) and 18 (2004) months after treatment with injected fungicides. Old foliage is current year's leaves; new foliage is newly emerging foliage. on in vitro screening of fungicides for use against Botrytis cine$\mathrm{rea}$, in which the $200 \mathrm{ppm}$ dose was found to be suitable for separating effective and ineffective fungicides (W. Littke, pers. comm.). Triazoles and benzimidazoles were most effective as fungicides against $F$. arbuti in culture. Li et al. (1995) using in vitro testing of fungicides against Botryosphaeria dothidea ( $\mathrm{Fu}$ sicoccum aesculi) found the most suppression of mycelial growth in plates containing carbendazim and thiophanatemethyl at concentrations of 50 and $100 \mathrm{ppm}$. These concentrations were lower than the $200 \mathrm{ppm}$ active ingredient concentration used in this study. Fosetyl-Al and phosphorous acid were both inhibitory to Phytophthora spp. in culture (Fenn and Coffey 1983) at concentrations ranging from 69 to $552 \mathrm{ppm}$, but we found they were not inhibitory to $F$. arbuti at $200 \mathrm{ppm}$. Fenn and Coffey (1983) report that these chemicals had low activity against a range of non-Oomycete pathogens so this result is not surprising.

Copper was more effective in inhibiting fungal growth than potassium, but after a period of time in culture, the fungus was observed to accumulate copper from the medium and isolate it. After that, the mycelium was able to grow unchecked. The melanized hyphae of Fusicoccum protected the mycelium from lysis by potassium salts. These fungicides are commonly used to control powdery mildews (Yildirim et al. 2002) whose hyphae may be more easily disrupted. The response to cinnamaldehyde was extremely variable, perhaps as a result of the volatility of the chemical.

There was variability in tolerance to some fungicides among the nine isolates of $F$. arbuti tested. All were completely inhibited by $200 \mathrm{ppm}$ of the triazole fungicides tebuconazole (Tebuject) and propiconazole (Alamo). In a study of sensitivity of $B$. dothidea to tebuconazole, Ma et al. (2001b) found that sensitivity to tebuconazole correlated significantly with sensitivity to propiconazole. Fungicide concentrations ranged from 0.0625 to $1.0 \mathrm{ppm}$, much lower than the $200 \mathrm{ppm}$ used in this study. Ma et al. (2001c) found that some isolates of $B$. dothidea developed resistance to iprodione (Rovral) in vitro and remained resistant when treated with up to $500 \mathrm{ppm}$ of the fungicide. There was a range of tolerance to this chemical among isolates of $F$. arbuti at $200 \mathrm{ppm}$, but the differences were not statistically significant.

Triazole and benzimidazole fungicides were the most effective against $F$. arbuti in vitro and we anticipated that this would translate to reduction of fungal growth in established infections. Inhibition of radial growth by chemicals with fungicidal activity can be an estimator of fungicidal activity in infected host canker tissue, and this was confirmed by some of the field results. However, not all the fungicides that performed well in culture did so in the field and vice versa. How well these chemicals behave in prevention of new infections was not tested in this study and should be done by measuring inhibition of spore germination.

\section{Field Tests of Systemic Treatments}

Because we did not want to introduce new genotypes of $F$. arbuti to the field site, we chose a local isolate of $F$. arbuti to be used in the field tests. There were no significant differences in sensitivity of isolates from the Puget Sound area to fungicides used in the field tests in vitro, so this isolate could be considered representative of the region. However, a more complete test should include isolates of $F$. arbuti from the entire range of Pacific madrone to fully account for genetic variability. 
Fusicoccum arbuti appears to be a wound-invading pathogen on woody tissue because $100 \%$ of wound inoculations on all trees developed cankers, whereas only $3 \%$ of surface inoculations did. No cankers developed from bark surface inoculations in the Arbotect $^{\circledR}$, BioSerum ${ }^{\mathrm{TM}}$, Cambistat, and Tebuject treatments. Perhaps defenses in the bark were stimulated, preventing fungal colonization.

The benzimidazole fungicides, with the exception of Arbotect $^{\circledR}$, performed less well in the field than in vitro. BioSerum ${ }^{\mathrm{TM}}$ (phosphorous acid) was the most effective fungicide in field tests. This is probably attributable to plant defenses being activated and not from fungicidal activity of the chemical. BioSerum $^{\mathrm{TM}}$ and a similar product, Aliette (Fosetyl-Al), were not inhibitory in culture. The previous in vitro fungicide results suggest the effectiveness of phosphorous acid is the result of stimulating plant defenses rather than direct fungicidal activity.

Treatment with phosphorous acid holds the most promise for madrones in disease prevention and in treating preexisting cankers. Because wounding and disease cause a defense response in trees (Percival 2001; Krokene et al. 2003), induced defenses already present resulting from active cankers on the tree before treatment with BioSerum ${ }^{\mathrm{TM}}$ were increased after treatment. Phosphorous acid, the active ingredient in BioSerum ${ }^{\mathrm{TM}}$, has been demonstrated to have a stimulatory effect on host defense responses to infection by Phytophthora spp. (Fenn and Coffey 1983).

Arbotect $^{\circledR}$ performed almost as well as BioSerum ${ }^{\mathrm{TM}}$ and a similar (induced) level of phenolic defense chemicals was seen in the foliage, but decreased in the second year after treatment. Cankers on these two treatments appeared to be more callused than on other treatments. Arbotect ${ }^{\circledR}$ may behave as a plant activator in addition to having fungicidal properties. Perhaps production of phenolic defense chemicals is less important than growth of callus tissue as a mode of plant defense initiated by these two chemical treatments, although increased foliar phenolics may prevent colonization by fungal pathogens.

All of these fungicides, except for benomyl, are sterol demethyation inhibitors and prevent formation of ergosterol in fungi. However, effectiveness of these fungicides may be the result of their behavior in the host rather than fungicidal activity. Sterol-inhibiting fungicides are known to change the balance of plant hormones and reduce transpiration rates in some crops (Lonsdale and Kotze 1993). This confers drought tolerance on the plant and possible resistance to canker fungi such as Botryosphaeria spp., that are pathogenic when the host is under water stress. New infections are prevented during times when stomates are closed.

\section{Implications for Arboriculture}

Treating Pacific madrone trees with phosphorous acid (BioSerum $^{\mathrm{TM}}$ ) or Arbotect ${ }^{\circledR}$ will stimulate their defenses and reduce the severity of cankers caused by $F$. arbuti. These treatments also will prevent some new infections through increased defense chemicals in the foliage. The treatment effect lasts at least 1 year. These treatments may be effective on diseases caused by Botryosphaeria spp. in other hosts in addition to Pacific madrone.

Acknowledgments. We thank Fred Ellis of Island Foresters and Debbie Hayward of Vulcan Corp. for assistance with fieldwork and chemical applications and Will Littke, Weyerhaueser Corporation, for help with laboratory work.

\section{LITERATURE CITED}

Afek, U., and A. Sztejnberg. 1989. Effects of Fosetyl-Al and phosphorous acid on scoparone, a phytoalexin associated with resistance of citrus to Phytophthora citrophthora. Phytopathology 79:736-739.

Anderson, R.D., R.M. Middleton, and D.I. Guest. 1989. Development of a bioassay to test the effect of phosphorous acid on black pod of cocoa. Mycological Research 93:110-112.

Brown-Rytlewski, D.E., and P.S. McManus. 2000. Virulence of Botryosphaeria dothidea and Botryosphaeria obtusa on apple and management of stem cankers with fungicides. Plant Disease 84:1031-1037.

Crist, C.R., and D.F. Schoenweiss. 1975. The influence of controlled stresses on susceptibility of European white birch stems to attack by Botryosphaeria dothidea. Phytopathology 65:369-373.

Davison, A.D. 1972. Factors affecting development of madrone canker. Plant Disease Reporter 56:50-52.

Elliott, M., R.L. Edmonds, and S. Mayer. 2002. Role of fungal diseases in decline of Pacific madrone. Northwest Science 76:293-303.

Farr, D.F., M. Elliott, A.Y. Rossman, and R.L. Edmonds. 2005. Fusicoccum arbuti sp. nov. causing cankers on Pacific madrone in western North America with notes on Fusicoccum dimidiatum, the correct name for Nattrassia mangiferae. Mycologia 97:730-741.

Fenn, M.E., and M.D. Coffey. 1983. Studies on the in vitro and in vivo antifungal activity of Fosetyl-Al and phosphorous acid. Phytopathology 74:606-611.

Graham, H.D. 1992. Stabilization of the Prussian blue color in the determination of polyphenols. Journal of Agricultural and Food Chemistry 40:801-805.

Haugen, L., and M. Stennes. 1999. Fungicide injection to control Dutch elm disease: Understanding the options. Plant Diagnosticians Quarterly 20:29-38.

Helton, A.W., and W.J. French. 1962. Toxicity and translocation characteristics of six fungicidal compounds in plum and prune trees. Phytopathology 52:1050-1056.

Helton, A.W., and A.E. Harvey. 1963. Absorption, toxicity and bioassay of high-potency fungicides in Prunus domesticus. Phytopathology 53:895-898.

Hunt, R.S., B. Callan, and A. Funk. 1992. Common Pests of Arbutus. Canadian Forestry Service, FPL 63, Victoria, BC, Canada.

Krokene, P., H. Solheim, T. Krekling, and E. Christiansen. 2003. Inducible anatomical defense responses in Norway spruce stems and their possible role in induced resistance. Tree Physiology 23: 191-197.

Lanier, G.N. 1988. Therapy for Dutch elm disease. Journal of Arboriculture 14:229-232.

Li, H.-Y., R.-B. Cao, and Y.-T. Mu. 1995. In vitro inhibition of Botryosphaeria dothidea and Lasiodiplodia theobromae, and chemical control of gummosis disease of Japanese apricot and peach trees in Zhejiang Province, China. Crop Protection (Guildford, Surrey) 14: 187-191.

Lonsdale, J.H., and J.M. Kotze. 1993. Chemical control of mango blossom diseases and the effect on fruit set and yield. Plant Disease 77:558-562.

Ma, Z., D.P. Morgan, and T.J. Michailides. 2001a. Effects of water stress on Botryosphaeria blight of pistachio caused by Botryosphaeria dothidea. Plant Disease 85:745-749.

Ma, Z., D.P. Morgan, D. Felts, and T.J. Michailides. 2001b. Sensitivity of Botryosphaeria dothidea from California pistachio to tebuconazole. Crop Protection (Guildford, Surrey) 21:829-835.

Ma, Z., Y. Luo, and T.J. Michailides. 2001c. Resistance of Botryosphaeria dothidea from pistachio to iprodione. Plant Disease 85:183-188.

Percival, G.C. 2001. Induction of systemic acquired resistance in plants: Potential implications for disease management in urban forestry. Journal of Arboriculture 27:181-192.

San Juan County Health and Community Services. 2000. San Juan County Watershed Action Plan. www.co.san-juan.wa.us/health/ wtrshdpln/index.html (accessed 4/2006). 
StatSoft, Inc. 2004. Electronic Statistics Textbook. Tulsa, OK: StatSoft. www.statsoft.com/textbook/stathome.html (accessed 4/2006).

Stipes, R.J. 1988. Glitches and gaps in the science and technology of tree injection. Journal of Arboriculture 14:165-172.

USFS. 2003. U.S. Forest Service Forest Insect and Disease Aerial Survey Data. www.fs.fed.us/r6/nr/fid/as/ (accessed 4/2006).

WRCC. 2006. Western Regional Climate Center Historical Climate Information. www.wrcc.dri.edu/ (accessed 4/2006).

Yildirim, I., E. Onogur, and M. Irshad. 2002. Investigations on the efficacy of some natural chemicals against powdery mildew [Uncinula necator (Schw.) Burr.] of grape. Journal of Phytopathology 150:697-702.

\section{Marianne Elliott (corresponding author) \\ Canadian Forest Service \\ Pacific Forestry Centre \\ 506 West Burnside Road \\ Victoria, BC, Canada V8Z 1M5 \\ melliott@nrcan.gc.ca}

\section{Robert L. Edmonds}

University of Washington

College of Forest Resources

Box 352100

Seattle, WA 98195, U.S.

Résumé. L'arbousier de Menzies (Arbutus menziesii) a souffert de dépérissement dans la région du détroit du Puget en raison principalement d'un chancre causé par le champignon pathogène Fusicoccum arbuti. Les méthodes culturales telles que la prévention des stress et la chirurgie sont des traitements recommandés pour les arbres atteints par le chancre. Des traitements par injection peuvent aussi être utilisés pour protéger l'arbousier de Menzies dans les zones urbaines. Une expérience mettant à l'essai l'injection de fongicides chimiques et de d'activateurs végétaux a été menée sur des arbousiers de Menzies inoculés avec $F$. arbuti. Dix-huit fongicides ont été testés en culture et sept parmi ces derniers lors de tests sur le terrain. Il y avait une faible corrélation entre l'activité fongique en milieu cultural et la réduction des chancres dans les tests sur le terrain. Deux traitements qui ont été efficaces pour minimiser la croissance des chancres sur des arbousier inoculés étaient l'Arbotect ${ }^{\circledR}$ (un fongicide à base de triazole) et le BioSerum ${ }^{\mathrm{TM}}$ (acide phosphorique). Les chancres inoculés sur des blessures étaient $50 \%$ plus petits que ceux du groupe témoin et aucune infection n'est survenue sur les sujets inoculés en surface. La formation d'un cal plus important a été observée autour des chancres sur des arbres avec ces traitements et le mode d'action de ces substances chimiques était probablement plus une stimulation des défenses de la plante qu'une action directe du fongicide. L'acide phosphorique est recommandé en sus aux méthodes culturales afin d'améliorer la vigueur de l'arbre, et ce pour les arbousier de Menzies de grande valeur dans les aménagements en milieu urbain.

Zusammenfassung. In der Puget Gegend erleidet die pazifische Baumerdbeere (Arbutus menziesii) einen Rückgang in erster Linie aufgrund einer Krebserkrankung, hervorgerufen durch den Pilz Fusicoccum arbuti. Kulturelle Methoden, wie Stressprävention und Wunden sind empfohlene Behandlungen bei Krebsbefall an Bäumen. Injizierte Behandlungen könne auch verwendet werden, um wertvolle Baumerdbeeren in urbanen Räumen zu schützen. Ein Experiment, welches injizierbare, chemische Fungizide und Pflanzenauslösen testet, wurde an infizierten Bäumen ausprobiert. 18 Fungizide wurden in Kultur getestet und sieben davon wurden im Freiland verwendet. Es gab nur eine geringe Korrelation zwischen der Pilzaktivität in Kultur und Krebsrückgang im Freiland. Zwei Behandlungen, die effektiv in der Reduzierung des Krebses waren, hießen Arbotect ${ }^{\circledR}$ (a triazole fungicide) und BioSerum $^{\mathrm{TM}}$ (Phosphorous acid). Die Inokulation von Krebswunden war $50 \%$ kleiner als die Kontrollgruppe und es traten keine Infektionen rund um die inokulierten Behandlungen auf. An Bäumen mit dieser Behandlung wurde vermehrt Kallusbildung beobachtet und die aktive Komponente in diesen Chemikalien ist vermutlich eher eine Stimulans der körpereigenen Abwehr als eine fungizide Wirkung. Phosphorsäure wird zusätzlich zu kulturellen Methoden empfohlen, um die Vitalität wertvoller Bäume in urbanen Gegenden zu verbessern.

Resumen. El madroño del pacífico (Arbutus menziesii) ha estado sufriendo declinación en el área de Puget Sound, primariamente debido a la enfermedad de cancro causada por el hongo Fusicoccum arbuti. Los métodos culturales tales como prevención del estrés y manejo de cavidades son tratamientos recomendados para enfermedades de cancro en los árboles. Los tratamientos con inyecciones también pueden ser usados para proteger madroños valiosos en áreas urbanas. Se realizó un experimento probando fungicidas químicos inyectables y activadores vegetales en árboles de madroño inoculados con $F$. arbuti. Fueron probados 18 fungicidas en cultivo, siete de los cuales fueron usados en pruebas de campo. Hubo poca correlación entre la actividad fungicida y la reducción del cancro en las pruebas de campo. Dos experimentos que fueron efectivos en minimizar el crecimiento del cancro en madroños inoculados fueron Arbotect ${ }^{\circledR}$ (un fungicida con triazol) y BioSerum ${ }^{\mathrm{TM}}$ (ácido fosfórico). Los cancros en las heridas inoculadas fueron $50 \%$ más pequeños que el grupo de control y no ocurrieron infecciones en los tratamientos sobre superficies inoculadas. Se observaron callos incrementados en cancros de árboles con estos tratamientos y el modo de acción para estos químicos es probablemente más la estimulación de las defensas de la planta que la acción fungicida. El ácido fosfórico es recomendado además de los métodos culturales que mejoran el vigor del árbol para madroños de alto valor en paisajes urbanos. 